\title{
Conflict and Reconciliation of International Genetically Modified Food Safety Legislation: China's Latest Development and Dilemma
}

\author{
Yayun Chen*
}

Genetically modified food gave rise to several controversies since it came into being. The clash of international GMF legislation is rooted in the divergence of the EU and the US legislation, which leads to the divergence of the WTO and Cartagena Protocol on Biosafety and indirectly influences the legislative choice of developing countries. Like other developing countries, China also faces lots of challenges including lag in genetically modified organism technology, disadvantage caused by invisible private standard, technical control of GMO companies in developed countries and low level of involvement of the public. In recent years, China adopts its own policy on GMO by developing GM technology cautiously. The legislative situation in China fall far behind domestic research and commercial production necessity. China has revised several existing legislations. Although there is far from perfect, it makes great progress. In the future, China is expected to be more active, positive and open towards GMO.

Keywords: GM Food, GMO, Conflict and Reconciliation, China, Legislative Reform

* Associate Professor at Henan University; Visiting Professor of Ghent University. A.B./LL.M./ Ph.D. (Wuhan). ORCID: https://orcid.org/0000-0001-9809-2190. This article is a result of National Philosophy and Social Science Youth Fund Project "Dilemma and Choice of Chinese GM Food Safety Legislation from the Perspective of International Law" (13CFX109). The author may be contacted at: Chenyayun1984@163.com/Address: Henan University Law School, Minglun Street No.85, Kaifeng City, P.R. China 475001. 


\section{INTRODUCTION}

A genetically modified organism ("GMO") is "an organism, with the exception of human beings, in which the genetic material has been altered in a way that does not occur naturally by mating and/or natural recombination." GMOs have advantages and disadvantages. In terms of advantages, first, it can increase crop yields, alleviate the food crisis, and help to eliminate hunger and poverty in developing countries. Second, to a certain extent, it can reduce use of herbicides and pesticides (more friendly to the environment) and helps to save money for input in pesticides. ${ }^{2}$ Disadvantages of GMO mainly lie in the potential risks to the environment and human health due to short time research and cultivation practices. In spite of potentials of GM crops to contribute to agricultural development, their introduction has led to significant oppositions. ${ }^{3}$ Due to limited technology, research time and insufficient clinical evidence, the public worries about its potential damage to human health and the environment.

Despite those concerns, GMO has moved from the experimental stage (since the 1980s) to large-scale commercial cultivation worldwide. As more countries have begun planting and sale of GM crops, its popularization and application rate are rapidly rising. James Clave provided:

\footnotetext{
An unprecedented cumulative hectares of 2 billion hectares of biotech crops, equivalent to twice the total land mass of China (956 million hectares) or the US (937 million hectares), were successfully cultivated globally in the 20 -year period 1996 to 2015; farmer benefits for the period 1996 to 2015 were estimated at over US\$150 billion. ${ }^{4}$
}

Today, there are 28 countries in the world planting GM crops, among which the US, Brazil, Argentina, India and Canada are top five. Also, more developing countries like Bangladesh has begun planting GM crops to benefit from it.

Because China is a developing country with a population of 1.3 billion, it often faces the challenges of food shortage and environmental protection. In this regard, China should consider planting the GM crops. For this measure, it is necessary for China to probe into the pros and cons of GM food ("GMF") through the different experiences between the EU and the US. This research aims to deal with the critical issues for China to make a right choice from a comparative legal 
perspective. This paper is composed of seven parts including Introduction and Conclusion. Part two will discuss conflict between the EU and the US on GMF safety legislation. Part three will analyze conflict between the WTO and CPB. Part four will study conflicts between developed and developing countries. Part five will examine the accomplishments and limitations of international reconciliation on Genetically Modified Food safety legislation. Part six will focus on latest development and dilemmas of Chinese Genetically Modified Food.

\section{Conflict Between the EU AND THE US ON GMF SAFETY Legislation}

\section{A. Different Legislative Principle}

The EU adopts the 'precautionary' principle, while the US supports 'preventive' principle. The EU became more precautionary than the US, although there were exceptions in both jurisdiction. ${ }^{5}$ The EU supports the precautionary principle which is manifested in its legislation and judicial practice. Consolidated Versions of the Treaty on European Union and the Treaty on the Functioning of the European Union Article 191 (ex Article 174 TEC) points out:

\footnotetext{
Union policy on the environment shall aim at a high level of protection taking into account the diversity of situations in the various regions of the Union. It shall be based on the precautionary principle and on the principles that preventive action should be taken, that environmental damage should as a priority be rectified at source and that the polluter should pay.
}

The White Paper on Food Safety explicitly provides that the European food safety policy is based on the precautionary principle. ${ }^{6}$ As the scholars points out, whether to support or not, the precautionary principle has become one of the core characteristics of the EU policy. ${ }^{7}$

In judicial practice, the European Court of Justice ("ECJ") supported the precautionary principle several times in its judgments such as in The Queen $v$. Ministry of Agriculture, Fisheries and Food ${ }^{8}$ and MOX Plant. ${ }^{9}$ In Alpharma Inc. v. Council of the European Union ${ }^{10}$ the ECJ reiterates its supportive position on the precautionary principle. The Court of First Instant which made a ruling in the 
Pfizer case ${ }^{11}$ in 2002 once again confirmed precautionary principle. Unlike the Alpharma case, in the Pfizer case, the Court not only affirmed rationality of the precautionary principle, but also interpreted the conditions of the precautionary principle, which was a long step development. ${ }^{12}$

Different from the EU, the US adopts the preventive principle. The US fundamentally recognizes the safety of GM food. As long as there are no substantial differences between final product and traditional food on function and safety, GM food and traditional food should be treated under the same standards. In this background, the discussion of GM food is not so fierce as in the EU. The following are the existing relative food legislations: the Food Safety Enhancement Act of 2009; ${ }^{13}$ the Federal Food Drug Cosmetic Act; FDA's Statement of Policy: Foods Derived From New Plant Varieties of $1992 ;{ }^{14}$ and Draft Guidance for Industry: Voluntary Labelling Indicating Whether Foods Have or Not Been Developed Using Bioengineering of 2001. ${ }^{15}$ All lack a systemic discussion of the scientific principle.

In judicial practice, on June 21, 2010, the US Supreme Court made a judgment on the first GM food case. Although it is the very first case accepted by the Supreme Court, its focus is not on safety of GMF. The district court, the court of appeal, and the Supreme Court all believed that such food was safe to human health and the environment. ${ }^{16}$

\section{B. Labelling System Difference}

The EU adopts 'mandatory' label system while the US implements 'voluntary' label system until August 2016 when President Barack Obama signed Bill 764. The EU's mandatory label system started with Council Directive of 3 April 1990 on the deliberate release into the environment of genetically modified organisms (90/220/EEC). ${ }^{17}$ Articles 12, 13 and 14 of Regulation on Genetically Modified Food and Feed $(1829 / 2003 / \text { EC })^{18}$ were provisions dedicated to the labeling of genetically modified food in detail. Article 4 of the Regulation on Traceability and Labeling of Genetically Modified Organisms and the Traceability of Food and Feed Products Produced from Genetically Modified Organisms (1830/2003/EC) ${ }^{19}$ set special rules for transgenic product traceability and label management. Article 7, which made amendment for directive 2001/18/EC, regulated that products in which GMO in a proportion higher than 0.9 percent should be labelled. 
For a long time, the US adopted a voluntary labeling system regarding compulsory labeling system as an exception. There is no special legislation on GM Food in the US. The label system refers to the Federal Food Drug and Cosmetic Act for the Regulation of Food Packaging. Article 403(1)(a) of the Act stipulates that it shall not use a false or misleading label. Article 201(n) provides that if tags do not manifest material information it is misleading. The FDA's Statement of Policy: Foods Derived from New Plant Varieties of 1992 explained labelling requirement as follows:

Section 403(i) of the act (21 U.S.C. 343(i)) requires that a producer of a food product describe the product by its common or usual name or in the absence thereof, an appropriately descriptive term (21 U.S.C. part 101.3) and reveal all facts that are material in light of representations made or suggested by labeling or with respect to consequences which may result from use (21 U.S.C. 343(a); 21 U.S.C. 321(n)). Thus, consumers must be informed, by appropriate labeling, if a food derived from a new plant variety differs from its traditional counterpart such that the common or usual name no longer applies to the new food, or if a safety or usage issue exists to which consumers must be alerted. ${ }^{20}$

The FDA has issued draft guidance of voluntary labeling of GMF and reaffirmed its labeling mechanism. ${ }^{21}$ Compulsory labeling system only refer to situation of allergy as an exception. ${ }^{22}$

However, the GMO labeling mechanism in the US changed in August 2016. Then, the Senate passed Bill $764^{23}$ which established mandatory label mechanism. In Section 293 of the Bill stipulates details requiring food manufacturers to use one of three different labels to inform consumers of the presence of GMOs in products. Manufacturers can comply it by providing a label that includes the US Department of Agriculture ("USDA") symbol indicating the presence of GMOs, print a label using plain language, or add a scanner- or smartphone-readable QR code that links to ingredient information. Small businesses also have the option to place a telephone number or internet website on packages that would direct customers to additional information. ${ }^{24}$

\section{Regulatory Models Difference}

The EU adopts 'process' management, while the US adopts 'product' management. 
The EU tries to monitor product process rather than a simple product as a result. When food is produced by GM technology, it then must be subject to strict control. The commission also distinguishes risk management from risk assessment and emphasizes the former. It means that policymakers should consider comprehensive social factors rather than merely scientific detection. Communication 2000 on the precautionary principle points out: "Recourse to the principle belongs in the general framework of risk analysis (which, besides risk evaluation, includes risk management and risk communication), and more particularly in the context of risk management which corresponds to the decision-making phase." ${ }^{25}$ The EU's approach is also manifested in the hormone beef case. Here, the EC repeatedly stressed that the 'consumption idea,' 'consumers' worry' and 'political pressure' were social value dimension as important influencing factors on the risk assessment. While panel experts believed that risk assessment was a scientific review on all kinds of data and facts, which, unlike risk management, did not involve considerations of social and economic factors. ${ }^{26}$ The US was against the EU regulation based on production process on GM food. Instead, it preferred regulations based on the final product without consideration of production technology and process.

\section{Conflict Between the WTO AND CPB}

\section{A. Difference of Aim and Scope}

The primary goal of the WTO is to promote trade in goods and services liberalization, to reach a mutually beneficial arrangement; to materially cut tariffs and eliminate trade barriers; and to reduce discrimination in international trade relations. ${ }^{27}$ In addition, the WTO considers trade-related measures influencing the environment, human rights, health protection, sustainable development, and treatment of developing countries. ${ }^{28}$ This legal principles were reinforced in latter judicial cases. $^{29}$

The Cartagena Protocol on Biosafety ("CPB") as the supplement of the Convention on Biological Diversity, following Principle 15 of the Rio Declaration on Environment and Development, concludes the precautionary measures and helps to ensure the safety in transferring, processing, and using of modern 
biotechnology, sustainable use of the modified living organisms within the territory and adequate protection measures to prevent cross-border transfer problems.

\section{B. Difference of Core Principle}

The WTO adopts the principle of prevention, while the CPB adopts the precautionary principle. The CPB in its preamble points out the precautionary approach contained in Principle 15 of the Rio Declaration on Environment and Development. Given the existing legislation and practice, the WTO generally supports principle of prevention. Article 5, paragraph 7 of the Sanitary and Phytosanitary ("SPS") Agreement points out: "In cases where relevant scientific evidence is insufficient, a Member may provisionally adopt sanitary or phytosanitary measures on the basis of available pertinent information..." The scientific principle is also explained and illustrated by the dispute settlement body in its judicial practice. Typical cases are the genetically modified food case and the hormone beef case. The precautionary principle is discussed in both cases. The Appellate Body also discussed its international legal status and relationship with the SPS Agreement. It finally concluded that SPS Agreement did not follow the precautionary principle.

\section{Conflicts Between Developed AND Developing CounTries}

The conflict between the EU and the US on GMF safety legislation affects developing countries' domestic GM policy and the legislative direction. Due to the opposite views between the EU and the US on GMF safety, developing countries have to make a choice between the two when they export such food. African countries are a good example whose most revenues rely on agricultural products and other primary products exportation. FAO's statistics (2005) show that agricultural exports account for 50 percent of the revenue, solve 80 percent of the population employment in Africa. "The Sub-Saharan Africa ("SSA") region accounts for more than 950 million people, approximately 13 percent of the world population. Despite ongoing transformation of the region's economies, agriculture remains a crucial sector providing livelihoods for millions of people.",31 
African countries' attitudes towards GMF are different. South Africa, Egypt and Malawi actively support research, development and cultivation of GM food. Kenya and Cameroon cautiously support it. Tanzania and Ethiopia are taking strict restrictions. One of the reasons for such opposition is related to the safety of GMF. Many African countries do not have domestic research and environmental monitoring technology on GMO, so that potential dangers of cultivation of GMO are hard to control. Another reason is the impact on agricultural exports. As scholars have pointed out, once African countries grow GM crops, their export of non GM crops are likely to lose European market, which accounts for about half of African agricultural exports. ${ }^{32}$

The EU refuses to import GMF from Africa, while the US sees the expansion of overseas GM food market as a long-term task through many different ways such as GMF aid ${ }^{33}$ and GM crop cultivation capacity building to help Africa to accept and cultivate GM crops. The United States Agency for International Development ("USAID") uses food crisis as an opportunity to increase the reliance of African countries to the US, forcing them to accept GM food. ${ }^{34}$ As the African market is relatively small, the main purpose for the US' aid to African countries is to win trust and support. ${ }^{35}$ In the long term, it will influence the African domestic GM legislation direction so as to affect the pattern of world trade in GM food.

There is one typical example-the change of position of Egypt in the WTO GMO case in 2003 -illustrating the impact of conflicts between the EU and the US towards developing countries. At the beginning of the lawsuit, Egypt was actively supporting the US, Canada and Argentina. Thereafter, it changed its position, dropping out the lawsuit not even as a third party on the vague grounds to protect the environment and consumers. The reasons for Egypt's out of lawsuit were unknown. Given that Egypt was the second largest recipient country of the American aid, however, the US would be unsatisfied with its performance. On June 19, 2003, the US senate finance committee chairman Grassley wrote to Egypt's Foreign Minister, claiming that if Egypt dropped the lawsuit it would consider to slow down or suspend the free trade area negotiations between the two countries. ${ }^{36}$ Actually, Egypt's agriculture export relies heavily on the EU market (30-40\%) and has also been accepting the EU bilateral economic aid. ${ }^{37}$ It might be really difficult for Egypt to say "yes or no" to either side. 


\section{AcComplishments and Limitations of INTERNATIONAL RECONCILIATION ON GMF SAFETY LegisLation}

\section{A. Accomplishments: Unified Standards by FAO,WHO, CAC and OECD}

In 2003, the International Codex Alimentarius Commission ("CAC") formulated Proposed Draft Recommendations for the Labelling of Foods Obtained through Certain Techniques of Genetic Modification/Genetic Engineering, ${ }^{38}$ Principles for the Risk Analysis of Foods Derived from Modern Biotechnology, ${ }^{39}$ Guideline for the Conduct of Food Safety Assessment of Foods Produced Using RecombinantDNA Microorganisms, ${ }^{40}$ Proposed Draft Guideline for the Conduct of Food Safety Assessment of Foods Derived from Recombinant-DNA Animals, and Proposed Draft Guideline for the Conduct of Food Safety Assessment of Foods Derived from Recombinant-DNA Plants. ${ }^{41}$ In the 24th session of the Codex Committee on Methods of Analysis and Sampling, CAC formulated guiding principles for detecting GMF, general, and specific recommendations. ${ }^{42}$

Compared with CAC, the contribution of the FAO and the WHO in GM food safety standards is more embodied in series of studies, evaluations and suggestions of the CAC work. Their reports mainly argue general safety of GMF, positive effects for maintaining food security of GM crop cultivation, necessity to strengthen the ability of biotechnology in developing countries and eliminate the gap between developed and developing countries, improvement of network of international food authorities, and supervision on the safety of genetically modified food. ${ }^{43}$

The OECD has been also concerned about biotechnology and GM food since 1982. As regard the question of GM food information gathering and sharing, the OECD published four important statistical reports. ${ }^{44}$ The latest report (2009) referred to the number, size, biotechnology research and development strength, financial and personnel of member states' biotechnology companies. ${ }^{45}$ From 2001 to 2010 , the OECD issued 22 documents on GM specific varieties such as papaya, tomatoes, sorghum, potatoes, sunflower, mushroom, alfalfa, barley, cotton, rice, animal feed, corn, sugar beets, soybean and rapeseed, respectively, discussing their nutrition, toxicity and allergy. ${ }^{46}$ In 2006, the OECD ratified the Genetically Modified Invention Licensing Guideline ${ }^{47}$ and the Human Genetic Research and 
Manage Database. ${ }^{48}$ In order to integrate scientists to do research on GM resources and share research results, in 2007, the OECD formulated intellectual property rights management cooperation mechanism to save research cost and to achieve win-win among different field researchers. ${ }^{49}$

\section{B. Shortcomings}

Although the above mentioned international organizations have tried to reconcile and harmonize standards and legislations worldwide, there are several deficiencies in outcome. In particular, documents issued by international organizations are mainly voluntary without legal binding effect. They are just reference and advice for member states and most of these documents are under drafting and discussion. As the actual influence is very limited, whether to comply with the rights and obligations of the relevant guidelines or standards for members is completely voluntary. Therefore, contents and wordings of these documents are quite vague and even contradictory.

Reasons for the lack of legal binding force and vagueness of documents of international organization are quite understandable. With large number of membership, the legislation must be result of bargaining among different countries. Its members include developed and developing countries; some of them are actively supporting the documents, others, not. As a result, the conflict between the EU and the US is very difficult to reconcile, not to mention facing so many different national practices and interests. The best way is to make compromise step by step to achieve the goal.

\section{Latest Development and Dilemmas of Chinese Genetically Modified Food}

\section{A. Contemporary Chinese GMF Commercial Practice}

China is the world's sixth largest producer of genetically modified crops, with a cultivation area of 3.7 million hectares mainly planting cotton, papaya and poplar. ${ }^{50}$ A careful analysis of the data, however, shows that Chinese GM crops cultivation scale is relatively smaller than top five countries such as the US (70.9 million hectares), Brazil (44.2 million hectares) Argentina (24.5 million hectares), 
India (11.6 million hectares), and Canada (11.0 million hectares). ${ }^{51}$ The ISAAA data (2012) shows that Chinese cultivation area was 3.9 million hectares in 2011 and 4.0 million hectares in 2012, which maintains a certain level without substantial growth, unlike Brazil increasing from 30.3 million hectares in 2011 to 44.2 million hectares in 2015 , nearly 45 percent growth. ${ }^{52}$

As regard the domestic GM crop, today, commercial cultivation practice is quite limited in China. Though the Chinese government attaches great importance to research and development of GM crops only six GM plants (cotton, tomato, sweet pepper, petunia, poplar, and papaya) have been approved since 1997. Among the six GM plants, only cotton, papaya and poplar are in commercial production. Among the three GM plants, GM cotton accounts for the vast majority. The USDA Foreign Agricultural Service provides: "At the farm-level from 1997 to 2014, the estimated realized economic gains from Bt cotton is USD 17.5 billion and USD 1.3 billion in 2014 alone. ${ }^{, 53}$ So far, China has not approved any kind of commercial production of main GM food crops. In 1999 and 2004, the Ministry of Agriculture ("MOA") accepted safety assessment application of GM rice and corn, insect-resistant rice varieties TT51, BtSY63 and one highphytase corn BVLA430101. ${ }^{54}$ In 2009, the Minister of Agriculture granted them a biosafety certification for the first time. However, granting a biosafety certification does not equal to permit commercial cultivation. Various commercial cultivation in China also needs to get production application. According to Seed Law of the People's Republic of China, main crops need to get various examinations and approvals. ${ }^{55}$ Seed production operators should get consent from the holder of the intellectual property right. ${ }^{56}$

China imports a lot of GMO only as industrial processing materials. The major import of GM crops are GM soybean, corn, cotton, sugar beet, oilseed rape. The number of approvals for importing GMO was declining for the past three years in 2016 (only 1 variety herbicide tolerant soybean FG72 from Bayer crop science), 2015 (16 varieties), and 2014 (20 varieties), respectively. ${ }^{57}$ In 2015, China imported over 80 million tons of soybeans, 2.98 million tons of corn (from Jan.-Sept.), 0.85 million tons of cotton (from Jan.-Sept.) and 2.698 million tons of distiller dried grains (from Jan.-Sept.). ${ }^{58}$ Besides cotton, with an exportation of 5703 million tons in 2016 (from Jan.-Sept.), China imported GMO much more than exports. 
China forbids the importation of GM seeds for commercial cultivation. In 2016, MOA revealed a roadmap for GMO application and development. At this stage, it cannot be eaten directly as food, but as feed or for industrial purposes. The ultimate goal is to use it as food. ${ }^{59}$

\section{B. Chinese Governmental Attitude and Policy on GMF}

Without unified GMF safety law and a clear legislative guiding ideology, the governmental attitude only can be overall concluded from the official leadership speech, legal wording, and the official questions and answers.

Generally, the government recognizes the GMF safety with safety assessment application certification no matter what produced domestically or imported from other countries. In the national policy level, it actively supports GMO research and development by increasing fiscal spending. The Chinese government emphasizes independent research and development of GM varieties and protection of intellectual property rights. At the same time, the government strengthens execution of the GMO regulation.

Governmental recognition of safety of GMF is mainly manifested in the following aspects. In 2010, the State Council's Information Office published "MOA answers to questions on GM technology and biological safety problems," in order to emphasize the advantages of GMO technology and its crucial function for food security and ecological environment protection. ${ }^{60}$ In 2016 , the Information Office of MOA, at a press conference on GMO, pointed out: "After safety evaluation and approval GM food was as safe as traditional food." ${ }^{61}$ The MOA website contains a special column named "GMO authoritative disclosure" [转基因权威关注] for the purpose of public propaganda and disclosure of latest information of GMO. ${ }^{62}$ Following the website, it is not hard to conclude that the Chinese government tries to prove and persuade the public trust in safety of GMF. Meanwhile, MOA and many experts try to clarify genetically modified risk events in the international level reported by media, eliminate consumers' concern about GM food, and enhance the public confidence. In addition, authoritative media such as Xinhua News Agency, Guangming Daily actively promote the safety of GM food, highlight the importance of GMF to Chinese food security and strategic reserve, and help to guide people to have comprehensive and correct understanding of GMF. 63 
On the national policy level, the Chinese government puts more investments into biological science regarding it as a long-term development task and priority support project. Such as GMO breeding in 2006 was a major project listed in the Long and Mid-term National Development Plan for Science and Technology (2006-20), which has mainly focused on crop (rice, wheat, corn and cotton) and animal (swine, cattle and sheep). In 2008, the National Development and Reform Commission in the medium and long term plan for the national food safety (200820) clearly put forward to start new variety cultivating projects. In July 2008, the State Council launched major projects of GMO breeding new varieties over 15 years with funding totaled RMB 24 billion. In June 2009, the State Council adopted several policies to promote the development of biological industry to speed up the biological breeding. ${ }^{64}$ By 2010, more than 13,000 researchers had been working for agricultural biotechnology, including GM plants, animals and microorganism. ${ }^{65}$ The 13th Five Year Plan for National Science and Technology Innovation issued by the State Council in August 2016 regarded GMO variety breeding as a major national science and technology projects. ${ }^{66}$ The total amount of Chinese government expenditures on biotechnology is estimated to be RMB 12 billion (approximate USD 1.9 billion) since 2008, far exceeding public sector investment in biotechnology than any other country including the US. ${ }^{67}$

\section{Chinese GMF Legislation: General View and Latest Reform}

Direct legislation on GM food safety includes one regulation of the State Council, three department rules and several regulations, and bulletins made by MOA, covering GM research, test, production, processing, management, import licensing examination and approval. In 2001, the State Council promulgated Regulations on Safety of Agricultural Genetically Modified Organisms. Next year, MOA formulated three supporting department rules, which were Implementation Regulations on Safety Assessment of Agricultural Genetically Modified Organisms, Implementation Regulations on the Safety of Import of Agricultural Genetically Modified Organisms and Implementation Regulations on Labeling of Agricultural Genetically Modified Organisms. In 2006, MOA drew up Regulations on Approval of Agricultural LMOs for Processing. There are also two regulations (Regulation on Inspection and Quarantine of Import and Export Genetically Modified Commodities \& Regulations on Examination and 
Approval of Forest Genetic Engineering Activities) and 34 bulletins issued by MOA. $^{68}$ Indirect legislation includes Product Quality Law of the People's Republic of China (1993), ${ }^{69}$ Food Safety Law of the People's Republic of China (2015), ${ }^{70}$ and Agricultural Product Quality Safety Law of the People's Republic of China (2006). ${ }^{71}$

Chinese GMF safety legislation have several shortcomings. Firstly, although there are a large number of GMF legislations, there is lack of a unified GMF safety legislation. The existing legislative level is quite old with low effective hierarchy. ${ }^{72}$ Secondly, the legislative provisions are quite simple and wordings are vague and unpractical. Take the most important Regulations on Safety of Agricultural Genetically Modified Organisms for example. Only eight chapters with 56 articles cover almost all aspects of GMF safety. ${ }^{73}$ Reading carefully the legislative contents, it is recognized too simple to actually play a role as guidance and specifications. Thirdly, many departments get involved in supervision with low efficiency. Though Article 4 of the Regulations on Safety of Agricultural Genetically Modified Organisms makes distinction between regulatory functions and powers, Article 5 sets up a joint inter-ministerial meeting of safety management system. Because of different department interests, however, it is difficult to fundamentally coordinate with each other. ${ }^{74}$

In the past few years, China revised some legislation related to GMF labelling, advertising and safety assessment. On October 1, 2015, the revised Food Safety Law of the People's Republic of China (Order of the Chairman of the People's Republic of China No.21) came into force. ${ }^{75}$ In the former Food Safety Law of the People's Republic of China in 2009, only Article $102^{76}$ referred to GMF, which was very general as a miscellaneous provision. The new Food Safety Law includes the GMF labeling and corresponding legal responsibility system.

In November 2015, China revised the Seed Law for the second time. Comparing to the 2011 Seed Law, the 2015 Seed Law has three articles which refer to safety assessment, labelling, importing GMO seeds. In spite of the change of provision number, the contents for the latter two are the same. The only difference regarding the safety assessment is that Article 7 of the 2015 Seed Law has added the following content to Article 14 of 2013 Seed Law: "The agriculture, the competent forestry department under the state council shall strengthen the supervision of tracking and provide information on the relevant examination and approval of GM plant varieties and promotion." The change mainly emphasizes 
regulatory responsibility and information disclosure. Accordingly, in 2016, MOA revised several implementing regulations in order to comply with new Seed Law such as Administrative Measures for Major Crops Variety Registration, Administrative Measures for Crop Seed Production and Operation Licensing, Administrative Measures for Labels and Use Instructions of Crop Seed. ${ }^{78}$

On January 22, 2015 the MOA Biosafety Office issued a notice on GMO advertisement. It stipulates:

For GMF in our country not approved import used as the feedstock, not approved for commercial cultivation domestically, not existing as genetically modified (gm) crops and processed products on the market, it is prohibited to use non-GMO advertisement; For GMF if it has been approved the import used as feedstock in China or has been commercially grown, do exist on the market of this kind of genetically modified crops and processed products, it can use non-GM but cannot use misleading advertisement indicating non-GMF is more healthy and safety. ${ }^{79}$

Besides, in September 2014, China Central Television ("CCTV") issued a notice to strengthen regulatory oversight over advertisements including claims or statements regarding GMOs. ${ }^{80}$

\section{China's Dilemma and Choice}

\section{Food security v. Uncertainty towards Human Health and Environment}

China faces huge population pressure and resource consumption. China also made great progress in poverty reduction. China's per capita water availability is only one fourth of the world average and its arable land accounts for only 8 percent of world total, but China supported over 20 percent of the world's population. ${ }^{81}$ The 2016 White Paper on China's Poverty Reduction Action and Human Rights Progress shows that since adopting the reform and opening up policy, more than 700 million poor people were out of poverty. ${ }^{82}$ As rural poverty population were reduced to 55.75 million by 2015 , the poverty rate fell to 5.7 percent. ${ }^{83}$ The Millennium Development Goals Report 2015 shows the extreme poverty rate had dropped significantly in China for the past 15 years. Proportion of people living on less than USD 1.25 per day decreased from 61 percent (1990) to 6 percent (2011), and even fell to 4.2 percent (2014). ${ }^{84}$ By contributing more than 70 percent to global poverty reduction, China has become the world's first country to complete 
the UN Millennium Development Goals. ${ }^{85}$

GMF supply contribute a lot to the rural population out of poverty. GM technology can greatly improve the food production, reduce plant diseases and insect pests, curb the international food prices and ease food crisis. Due to limitation of research time, there may exist potential negative impact towards environment and human health. Responding to these harmful effects, the EU has formulated and promulgated a series of rules and instructions adjusting GMO experimental safety, preventing the leak damage towards staff health and ecological environment, and ensuring safe coexistence of GM crops and non GM crops. Even in the US, the environmental impact of GMO is still strictly regulated mainly by the Environmental Protection Agency ("EPA").

\section{The EU Mode or the US Mode?}

There are several differences between the EU and the US. The EU insists the precautionary principle, while the US adopts scientific principle. The advantages of the precautionary principle are high level of control risk, protection interests of consumers, and the ecological environment security. However, the shortcomings include high economic cost of commodity production, management costs, and vagueness and uncertainty during the application of the principle. The advantages of the scientific principles are conceptual preciseness, easy and consistent implementation and increase of grain output in the short and medium term. Conversely, the scientific principles may not be able to eliminate the consumer concerns about potential influence because it can only make remedy after accidents.

The Chinese attitude and legislation on GMO have a certain tendency. In this regard, China should seriously consider a large population base, the cultivated land decreasing, increasing demand for food, low consumer rejection of GMO, and gradually increased domestic and foreign environmental protection pressure. Therefore, China cannot simply follow the US or the US legislation pattern. Instead, it should find a suitable way to cope with the current development of GM food in China from its own experience. All in all, China should adopt scientific principles, simultaneously taking preventive measures to control risk at early stage.

China should also improve and strengthen the traditional food safety legislation. 
In fact, it is unrealistic for a country with a low level of legislation and supervision on traditional food to formulate and implement a high level of genetically modified food safety legislation.

\section{Foreign GMF Seed Monopoly v. Local Private Company Lack of Initiative}

Agricultural chemical and seed industries are now consolidated and controlled by just six large multinational corporations such as Monsanto (US), Dupont/ Pioneer (US), Dow (US), Bayer (Germany), Syngenta (Switzerland), and BASF (Germany), which mostly dominate the world market. ${ }^{87}$ It is quiet dangerous for developing countries because they heavily rely upon importation of GM seed from those companies.

To prevent the monopoly of a large foreign biotechnology company, currently, China has not approved the import of any foreign GM seeds. China also prohibits the foreign investment in research and production of biotech plants, livestock and aquatic product. Foreign investment is only allowed in convention/hybrid seed production, only in terms of minority shares in joint ventures with Chinese companies. ${ }^{88}$ The Chinese government pays great attention to the development of agricultural biotechnology and invests financial funds in supporting the domestic research and development of GM crops seeds.

Different from the public sector which invests in agricultural biotechnology, private seed breeding companies are not very enthusiastic to invest in GM crops in China. Due to the lack of a clear path to commercialize major biotechnology crop varieties (other than cotton), local seed companies have limited incentives to invest in biotechnology. ${ }^{89}$ In February 2016, Chinese chemicals group, Chemchina offered more than USD 43 billion to take over Swiss agribusiness giant Syngenta. ${ }^{90}$ It shows China's ambition and determination to safeguard food security. In the world seed market, nonetheless, China is still not strong enough to compete with other giants. The revised Seed Law of 2015 tries to improve this situation. However, without approval of GM crops commercial cultivation this law cannot fundamentally solve the problem.

\section{Pressure from Conflicts of EU and US, WTO and CPB}

The US and the EU are the largest agricultural products import and export trade partners of China. China is a member of both the WTO and CPB. Conflicts 
between the EU and the US, the WTO and CPB are both an opportunity and challenge for China. On the one hand, within the framework of the WTO and $\mathrm{CBP}$, the EU and the US would provide economic and technical assistance to developing and least developed countries in order to dominate the GMO's operational principles. Through this aid, developed countries will ultimately affect developing and the least developed countries' domestic polices and legislation, expand their camp, and consolidate power throughout the world. Against this backdrop, developing countries should improve research capacity of GMO. On the other hand, developing and least-developed countries can only survive between the margins of the US and the EU. Domestically, China has to face huge demand for food, while internationally it has to consider export resistance from the EU which is not favorable to GM food. ${ }^{91}$

China, as a developing country and a latecomer of the WTO and CPB, should strengthen its voice in the world. Current rules are the product of the negotiations and interests bargaining between the developed countries, in which developing countries have not fully reflected their interests. Therefore, China should actively participate in a new round of negotiations for the revision of international agreements including the UN framework of GM food related rules.

\section{China's Choice: Development of GM Technology with Cautiousness}

Policymakers attach great importance to the strategic significance of GM food towards food security. In a speech on December 23, 2013 at the Central Conference on Rural Work by the Central Committee of the Communist Party, President Xi Jinping emphasized "bold in research but cautious in commercialization." ${ }^{, 92}$ For the past three years, the Chinese Communist Party pledged to strengthen research and safety management of GM biotechnology. ${ }^{93}$ No.1 Documents of both 2016 and 2017 strengthen the research and regulation of agricultural GM technology and popularization on the basis of safety and discreetness. ${ }^{94}$ Different from other No.1 Documents which have mentioned the importance of biotechnology research, No.1 Document of 2015 for the first time called on the government to conduct public outreach and to popularize biotechnology. ${ }^{95}$

Meanwhile, due to relatively backward research, the Chinese government forbids cultivation of GM crops and import of GM seeds. MOA draws the outline of the GM technology roadmap: from not for food use, followed by input for 
feed and industrial use, and to finally for food use. In order to prevent foreign big companies' monopoly on technology and GM seeds, the Chinese government should promote domestic research and provide huge fiscal investment.

The policy and practice in China on GMO may be quite controversial. In the near future, China will be increasing input towards GMO research and enhancing intellectual property right protection. When China can compete with big giants from developed countries, it will promote GM crops cultivation, permit and enlarge GM seeds importation. At the same time, China should pay more attention to perfect legislation and public acceptance.

\section{Conclusion}

The clash of international GMO food legislation is rooted in the divergence between the EU and the US, which influences on not only the divergence of the WTO and CPB, but also the legislative choice of developing countries. Different legislations between the EU and the US legislations are mainly due to economic benefit and consumer attitude. However, reconciliation should be made step by step.

Developing countries are sharing certain commons in GMO technology and legislation such as lag in technology, limit by invisible private standard, technical control of GMO companies in developed countries, the public financial support and lower level of involvement of public. Because of differences in natural environment, the importance of agriculture to GDP and the reliance degree to the European and American market, developing countries also manifest the gap from each other. Both the EU and the US try to support developing countries to take initiative for leading international GMO legislation by ways of bilateral and multilateral aid. In this course, they are willing to influence domestic policies and legislation of developing countries.

Though such organizations like FAO, WHO, CAC and OECD made some reconciliation efforts, voluntary and instructive guidelines without legal effect cannot fundamentally change the situation of conflict worldwide. Ultimate reconciliation can be only obtained in the long term resolutions of those international organizations as soft law might be forerunner of international treaty 
and customary law.

So far, the Chinese government has paid full attention to GMO researches and emphasized the importance of GMF security. In toto, China will continue to support GM technology positively. As China relies much on its own capacity, however, it would not open its door to western GM seeds giants in the near future. What's worse, China's legislation is far behind domestic research and commercial production necessities. China should finally choose to adopt the principle: "bold in research but cautious in commercialization."

\section{REFERENCES}

1. A definition of GMO may be found at Article 2 of Directive 2001/18/EC of the European Parliament and of the Council of 12 March 2001 on the deliberate release into the environment of genetically modified organisms and repealing Council Directive 90/220/EEC. The WHO also give the same definition about GMO. See Frequently ASKED QUESTIONS ON GENETICALLY MODIFIED FOODS available at http://www.who.int/foodsafety/areas_work/foodtechnology/Frequently_asked_questions_on_gm_foods.pdf?ua=1 (last visited on Aug. 8, 2018).

2. ISAAA Brief 51-2015: Executive Summary, available at http://www.isaaa.org/resources/ publications/briefs/51/executivesummary/default.asp (last visited on Aug. 8, 2018).

3. N. Gilbert, Case studies: A hard look at GM crops, 497 Nature 24-6 (2013).

4. J. Clive, ISAAA Briefs 51: 20 Anniversary (1996 to 2015) of the Global Commercialization of Biotech Crops and Biotech Crop Highlights in 2015, available at https://www.isaaa.org/ resources/publications/briefs/51/download/isaaa-brief-51-2015.pdf (last visited on Aug. 6, 2018).

5. D. Vogel, The Politics of Precaution: Regulating Health, Safety, and Environmental Risks in Europe and the United States (2012). See also L. Carothers Upholding EPA Regulation of Greenhouse Gases: The Precautionary Principle Redux (case discussion), 41 Ecology L. Q. 683-747 (2015).

6. Commission of the EC, White Paper on Food Safety, COM (1999) 719 final, Jan. 12, 2000, available at https://eur-lex.europa.eu/legal-content/EN/TXT/PDF/?uri=CELEX:51999DC071 9\&rid=4 (last visited on Aug. 8, 2018).

7. S. Woolcock, The Precautionary Principle in the European Union and its Impact on International Trade Relations, CEPS Working Document No. 186, (2002), at 1, available at https://www.ceps.eu/publications/precautionary-principle-eu-and-its-impact-internationaltrade-relations (last visited on Aug. 8, 2018). 
8. The Queen v. Ministry of Agriculture, Fisheries and Food, Commissioners of Customs \& Excise, ex parte National Farmer's Union, David Burneett and Sons Ltd, R.S. Case C-157/96 [1998].

9. The MOX Plant Case (Ireland v. U.K.), Case No.10, Order of 13 November 2001, ITLOS Rep. 89, reprinted at 41 I.L.M. 405 (2002), available at https://www.itlos.org/fileadmin/itlos/ documents/cases/case_no_10/published/C10-O-13_nov_01.pdf (last visited on Aug. 8, 2018).

10. Case T-70 /99, Alpharma Inc. v. Council of the European Union, 2002 E.C.R. II-03495 (Sept. 11, 2002), available at file://C:/Users/user/AppData/Local/Microsoft/Windows/ INetCache/IE/4HUAGB07/document.pdf (last visited on Aug. 8, 2018).

11. Case T-13/99, Pfizer Animal Health SA V. Council of the European Union, 2002 E.C.R. (Sept. 11, 2002), available at file://C:/Users/user/AppData/Local/Microsoft/Windows/ INetCache/IE/3LCSH9VO/document.pdf (last visited on Aug. 8, 2018).

12. Wybe Th. Douma, Fleshiing Out the Precautionary Principle by the Court of First Instance, 15 J. EnvtL. L. 394 (2003), available at https://academic.oup.com/jel/article-abstract/15/3/3 72/388471?redirectedFrom=PDF (last visited on Aug. 8, 2018).

13. Food Safety Enhancement Act of 2009 (H.R. 2749 RFS), available at https://www.govtrack. us/congress/bills/111/hr2749/text (last visited on Aug. 8, 2018).

14. FDA, Statement of Policy: Foods Derived from New Plant Varieties, 57 FR 22984, May 29, 1992, available at https://www.fda.gov/Food/GuidanceRegulation/GuidanceDocumentsReg ulatoryInformation/Biotechnology/ucm096095.htm (last visited on Aug. 8, 2018).

15. R. Hildwine, Draft Guidance for Industry: Voluntary Labeling Indicating Whether Foods Have or Have Not Been Developed Using Bioengineering, 66 FR 4839, Jan. 18, 2001, available at $\mathrm{https} / / \mathrm{www} . g p o . g o v / f d s y s / p k g / F R-2001-01-18 / \mathrm{html} / 01-1047 . h t m$ (last visited on Aug. 8, 2018).

16. Monsanto Co. et al. v. Geertson Seed Farms et al., Certiorari to the U.S. Court of Appeals for the Ninth Circuit, Decided June 21, 2010, 561 U.S. 139 (2010).

17. Council Directive of 3 April 1990 on the deliberate release into the environment of genetically modified organisms (90/220/EEC), pt. C.

18. Regulation on Genetically Modified Food and Feed, 1829/2003/EC.

19. Regulation on Traceability and Labeling of Genetically Modified Organisms and the Traceability of Food and Feed Products Produced From Genetically Modified Organisms, 1830/2003/EC.

20. Biotechnology - Statement of Policy: Foods Derived from New Plant Varieties, the official website of the US Food and Drug Administration, May 29, 1992, at 22984, available at https:/www.fda.gov/Food/GuidanceRegulation/GuidanceDocumentsRegulatoryInformati on/Biotechnology/ucm096095.htm (last visited on Aug. 6, 2018).

21. Draft Guidance for Industry: Voluntary Labelling Indicating Whether Foods Have or Not Been Developed Using Bioengineering, 66 FR 4839, Jan. 18, 2001, available at https:// www.federalregister.gov/documents/2001/01/18/01-1047/draft-guidance-for-industry- 
voluntary-labeling-indicating-whether-foods-have-or-have-not-been (last visited on Aug. 8, 2018).

22. Statement of Policy: Foods Derived from New Plant Varieties 57 FR 104, May 29, 1992, at 22991, available at https:/www.fda.gov/Food/GuidanceRegulation/GuidanceDocumentsRe gulatoryInformation/Biotechnology/ucm096095.htm (last visited on Aug. 8, 2018).

23. National Bioengineered Food Disclosure Standard (S. 764), available at https://www. congress.gov/114/bills/s764/BILLS-114s764enr.pdf (last visited on Aug. 8, 2018).

24. D. LugoJul, U.S. Senate passes GM food labeling bill, ScI., July 8, 2016, available at http:// www.sciencemag.org/news/2016/07/us-senate-passes-gm-food-labeling-bill (last visited on Aug. 8, 2018).

25. EUR-Lex Access to European Union law, EUR-LeX - 31995L0046 - EN, available at http:// eur-lex.europa.eu/legal-content/EN/TXT/?uri=URISERV:132042 (last visited on Aug. 8, 2018).

26. Panel Report, EC Measures Concerning Meat and Meat Products (Hormones), WTO Doc. WT/DS26/R/USA (adopted Aug. 18, 1997), § 40/92, available at https://www.wto.org/ english/tratop_e/dispu_e/26rusa.pdf (last visited on Aug. 8, 2018).

27. WTO, What is the WTO? - Who we are, available at https://www.wto.org/english/docs_e/ legal_e/04-wto_e.htm (last visited on Aug. 8, 2018).

28. Id.

29. E.g., cases related to GATT1994 Article XX (general exceptions), in which Panel and Appellate Body tended to be very discreetly to interpret and apply in order to maintain free trade are the US-Gasoline case, the US-Shrimp case, China-Raw Materials case, MexicoTaxes on Soft Drinks, etc.

30. FaO, The State of Food and Agriculture 2005 - Agricultural Trade and Poverty: Can Trade Work For the Poor? Figure 51 \& Table A4 (2005), available at file:///C:/Users/user/ AppData/Local/Microsoft/Windows/INetCache/IE/3ILT3G2Q/a0050e_full.pdf (last visited on Aug. 8, 2018).

31. OECD-FAO Agricultural OutLook 2016-2025 at 18, available at file:///C:/Users/user/ AppData/Local/Microsoft/Windows/INetCache/IE/7VJQZEFJ/a-i5778e.pdf (last visited on Aug. 8, 2018).

32. S. Zarrilli, International Trade in GMOs: Legal Frameworks and Developing Country Concerns (UNCTAD, 2004), available at file://C:/Users/user/AppData/Local/Microsoft/ Windows/INetCache/IE/3LCSH9VO/ditctncd20041_en.pdf (last visited on Aug. 8, 2018).

33. Many South African countries refused to accept genetically modified corn provided by the US as food aid in 2002. Some countries agreed to accept grinded GM corn, but Zambia still refused to accept grinded GM corn. For details, see GM Food Aid: Africa Denied Choice Again?, a publication of the Africa Center for Biosafety, Earthlife Africa, Enviromental Rights Action-Friends of the Earth Nigeria, Grain and SafeAge (May 2004), available at file://C:/Users/user/AppData/Local/Microsoft/Windows/INetCache/IE/7VJQZEFJ/ACB_ 
GM_food_aid_Africa_denied_choice_once_again.pdf (last visited on Aug. 11, 2018).

34. N. Zerbe, Feeding the famine? American food aid and the GMO debate in Southern Africa, 29 Food PoL'y 593-608 (2004), available at file:///C:/Users/user/AppData/Local/Microsoft/ Windows/INetCache/IE/7VJQZEFJ/Zerbe\%20-\%20GMOs\%20in\%20food\%20aid.pdf (last visited on Aug. 8, 2018).

35. T. Bernauer \& P. Aerni, Competition for Public Trust: Causes and Consequences of Extending the Transatlantic Biotech Conflict to Developing Countries, in InTERnationaL Politics of Genetically Modified Food 138-54 (R. Falkner ed., 2006), available at https:// link.springer.com/chapter/10.1057\%2F9780230598195_9 (last visited on Aug. 8, 2018).

36. FAO AGRIS, GM Food Aid: Africa Denied Choice Again? 141 (2004), available at http:// agris.fao.org/agris-search/search.do?recordID=GB2013202695 (last visited on Aug. 8, 2018).

37. European Commission, European Economy Occasional Paper: Economic Review of EU Mediterranean Partners (Jan. 2003), available at file://C:/Users/user/AppData/Local/ Microsoft/Windows/INetCache/IE/3ILT3G2Q/publication990_en.pdf (last visited July 30, 2018).

38. Appendix v. Proposed Draft Recommendations for the Labelling of Foods Obtained through Certain Techniques of Genetic Modification/Genetic Engineering, FAO, available at http:// www.fao.org/docrep/meeting/005/y0651e/y0651e0o.htm (last visited on Aug. 8, 2018).

39. Principles for the Risk Analysis of Foods Derived from Modern Biotechnology, CAC/GL 44-2003, available at file://C:/Users/user/AppData/Local/Microsoft/Windows/INetCache/ IE/4HUAGB07/CXG_044e.pdf (last visited on Aug. 8, 2018).

40. Guideline for the Conduct of Food Safety Assessment of Foods Produced Using Recombinant-DNA Microorganisms, CAC/GL 46-2003, available at file://C:/Users/user/ AppData/Local/Microsoft/Windows/INetCache/IE/3LCSH9VO/CXG_046e.pdf (last visited on Aug. 8, 2018).

41. Report of the Sixth Session of the Codex Ad Hoc Intergovernmental Task Force on Foods Derived from Biotechnology, Chiba, Japan, 27 November-1 December 2006, CL 2006/54FBT, available at https://www.mhlw.go.jp/english/topics/foodsafety/dna/02-03.html\#06 (last visited on Aug. 8, 2018).

42. Criteria for the Methods for the Detection and Identification of Foods Derived from Biotechnology General Approach and Criteria for the Methods, Joint FAO/WHO Food Standards Programme Codex Committee on Methods of Analysis and Sampling Twentyfifth Session, Budapest, Hungary, Mar. 8-12, 2004, available at http:/www.fao.org/tempref/ codex/Meetings/CCMAS/ccmas25/ma04_10e.pdf (last visited on Aug. 12, 2018).

43. WHO, Modern Food Biotechnology, Human Health and Development: An Evidence-based Study, Food Safety Department, (2005), at 24, available at file://C:/Users/user/AppData/ Local/Microsoft/Windows/INetCache/IE/7VJQZEFJ/biotech_en.pdf (last visited on Aug. 8, 2018). 
44. B. van Beuzakom, Biotechnology Statistics in OECD Member Countries: An Inventory, OEDC Science Technology and Industry Working Papers (2000); B. van Beuzakom, Biotechnology Statistics in OECD Member Countries: An Inventory, OECD Science Technology and Industry Working Papers (2004); B. van Beuzakom \& A. Arundel, OECD Biotechnology Statistics 2006, available at http://www.oecd.org/document/9/0,3746, en_2649_34391_1812041_1_1_1_1,00.html (last visited on Aug. 8, 2018).

45. B. van Beuzakom \& A. Arundel, OECD Biotechnology Statistics 2009.

46. Van Beuzakom \& Arundel, supra note 44.

47. OECD Guidelines for the Licensing of Genetic Inventions, available at http://www.oecd. org/sti/biotech/guidelinesforthelicensingofgeneticinventions.htm (last visited on Aug. 8, 2018).

48. OECD, Creation and Governance of Human Genetic Research Database (2006), available at http://www.oecd.org/health/biotech/creation-and-governance-of-human-genetic-researchdatabases.htm (last visited on Aug. 8, 2018).

49. OECD, Collaborative Mechanisms for the Manegement of Intellectual Property (2007), available at file:///C:/Users/user/AppData/Local/Microsoft/Windows/INetCache/IE/ 4HUAGB07/48665248.pdf (last visited on Aug. 8, 2018).

50. Statistic given by MOA has a little different from ISAAA. For example, as of April 13, 2016, China planted only GM cotton and papaya without poplar. See Information Office of MOA Press Conference on GMO, available at http://www.moa.gov.cn/zwllm/zwdt/201604/ t20160413_5093642.htm (last visited on Aug. 8, 2018). For details, see J. Clive, Executive Summary of 20th Anniversary of the Global Commercialization of Biotech Crops (1996 to 2015) and Biotech Crop Highlights (2015), at 2, available at http:/www.isaaa.org/resources/ publications/briefs/51/executivesummary/default.asp (last visited on Aug. 8, 2018).

51. Clive, $i d$.

52. C. James, Global Status of Commercialized Biotech/GM Crops (2013).

53. USDA Foreign Agricultural Service, China Moving towards Commercialization of Its Own Biotechnology Crops, GAIN Report Number CH16065, Dec. 16, 2016, at 4, available at file://C:/Users/user/AppData/Local/Microsoft/Windows/INetCache/IE/3LCSH9VO/ Agricultural\%20Biotechnology\%20Annual_Beijing_China\%20-\%20Peoples\%20 Republic\%20of_12-16-2016.pdf (last visited on Aug. 8, 2018).

54. The second batch of agricultural GMOs safety certificate approval list in 2009 [2009年第 二批农业转基因生物安全证书批准清单], available at http://www.moa.gov.cn/ztzl/zjyqwgz/ spxx/201202/P020120203355472286958.pdf (last visited on July 22, 2018).

55. PRC Seed Law, first enacted on July 8, 2000; last amended on Nov. 4, 2015, art. 15.

56. Id. art. 25.

57. Approved list of safety certificate for production and application of agricultural GMOs in 2016 [2016年农业转基因生物生产应用安全证书批准清单], available at http://www.moa.gov. cn/ztzl/zjyqwgz/spxx/201701/t20170105_5425354.htm (last visited on Aug. 8, 2018). 
58. USDA Foreign Agricultural Service, supra note 53.

59. The Press Office of the Ministry of Agriculture held a press conference to answer questions on agricultural GM [农业部新闻办公室举行新闻发布会就“农业转基因有关情况”答记者问], available at http://www.moa.gov.cn/zwllm/zwdt/201604/t20160413_5093642.htm (last visited on Aug. 8, 2018).

60. The Ministry of Agriculture answers questions on agricultural GM technology and biosafety [农业部就农业转基因技术与生物安全等问题答问], available at http://www.scio.gov.cn/xwfbh/ xwbfbh/wqfbh/2010/0716/xgfbh/Document/705380/705380.htm (last visited on Aug. 8, 2018).

61. Supra note 59.

62. Popular science propaganda [科普宣传], available at http://www.moa.gov.cn/ztzl/zjyqwgz/ kpxc (last visited on Aug. 8, 2018).

63. See Expert: there is no evidence that gm food is unsafe for humans and animals, GuANGMING DAILY, June 11, 2010, available at http://www.gov.cn/fwxx/jk/2010-06/11/content_ 1625441.htm; Summary: China actively promotes the sustainable and healthy development of bio-breeding industry, XinHuANET, Feb. 25, 2010, available at http://www.gov.cn/ jrzg/2010-02/25/content_1541832.htm (all last visited on Aug. 8, 2018).

64. The Ministry of Agriculture Answers Questions on Agricultural GM Technology and Biosafety [农业部就农业转基因技术与生物安全等问题答问], available at http://www.gov.cn/ gzdt/2010-03/15/content_1555803.htm (last visited on Aug. 8, 2018).

65. Jikun Huang, Impacts of Agricultural Biotechnology and Policies: China's Experience, in FAO International Symposium on the Role of Agricultural Biotechnologies in Sustainable Food Systems And Nutrition 41 (2016), available at http://www.fao.org/3/a-bc562e.pdf (last visited on Aug. 8, 2018).

66. Outline of the 13th Five-Year Plan for the National Economic and Social Development of the People's Republic of China [中华人民共和国国民经济和社会发展第十三个五年规划纲要 ], XINHUANET, Mar. 17, 2016, available at http://news.xinhuanet.com/politics/ 20161h/201603/17/c_1118366322.htm (last visited on Aug. 8, 2018).

67. USDA Foreign Agricultural Service, supra note 53.

68. Biosafety Clearing-House, Country Profile: China, available at https://bch.cbd.int/database/ results?searchid=673712 (last visited on Aug. 8, 2018).

69. Product Quality Law of the People's Republic of China of 2000, available at http://www. most.gov.cn/eng/policies/regulations/200501/t20050105_18422.htm (last visited on Aug. 8, 2018).

70. Food Safety Law of the People's Republic of China (Order No. 9 of the President of the People's Republic of China) [中华人民共和国食品安全法(主席令第二十一号)], available at http://www.gov.cn/zhengce/2015-04/25/content_2853643.htm (last visited on Aug. 8, 2018).

71. Agricultural Product Quality Safety Law of the People's Republic of China, available at 
http://www.lawinfochina.com/display.aspx?id=5142\&lib=law (last visited on Aug. 8, 2018).

72. See NPC Delegate: to Speed up the Formulation of GMF Safety Legislation, XINHUANET, Mar. 11, 2010, available at http://www.gov.cn/2010lh/content_1553412.htm (last visited on Aug. 8, 2018).

73. Regulations on the Safety Management of Agricultural Genetically Modified Organisms [农业转基因生物安全管理条例], available at http://jiuban.moa.gov.cn/fwllm/zxbs/xzxk/ bszl/201405/t20140527_3918108.htm (last visited on Aug. 8, 2018).

74. Wang Na, International Law Control of Genetically Modified Products (2015), (unpublished Ph.D. dissertation, CUPL) (on file with author), at 104.

75. Food Safety Law of the People's Republic of China, available at http://www.gov.cn/ zhengce/2015-04/25/content_2853643.htm (last visited on Aug. 8, 2018).

76. Article 102 stipulates: "Milk, genetically modified food, pig slaughtering, alcohol and salt food safety management, this law shall apply; otherwise stipulated by laws, administrative regulations, such provisions shall apply."

77. Article 14 stipulated: "The selection, experiment, verification and popularization of transgenic plant varieties shall be subject to security assessment, and strict security control measures shall be taken. Specific measures in this respect shall be formulated by the State Council."

78. USDA Foreign Agricultural Service, China's Planting Seeds Market Continues to Grow, GAIN Report Number CH16066, Jan. 17, 2017, available at file://C:/Users/user/AppData/ Local/Microsoft/Windows/INetCache/IE/7VJQZEFJ/China's\%20Planting\%20Seeds\%20 Market\%20Continues\%20to\%20Grow_Beijing_China\%20-\%20Peoples\%20Republic\%20 of_1-17-2017.pdf (last visited on Aug. 8, 2018).

79. Notice on Guidance on GM Advertising Management [关于指导做好涉转基因广告管理工作的 通知], available at http://www.moa.gov.cn/ztzl/zjyqwgz/zcfg/201501/t20150122_4346780. htm (last visited on Aug. 8, 2018).

80. USDA Foreign Agricultural Service, China Considering Major Revisions to Biotechnology Regulations, GAIN Report Number CH16032, Dec. 21, 2015, available at file://C:/Users/ user/AppData/Local/Microsoft/Windows/INetCache/IE/3LCSH9VO/Agricultural\%20 Biotechnology\%20Annual_Beijing_China\%20-\%20Peoples\%20Republic\%20of_12-212015.pdf (last visited on Aug. 8, 2018).

81. Huang, supra note 65.

82. White Paper on China's Poverty Reduction Action and Human Rights Progress in 2016, available at http://www.gov.cn/zhengce/2016-10/17/content_5120140.htm\#allContent (last visited on Aug. 8, 2018).

83. Id.

84. The Millennium Development Goals Report 2015, available at http://www.un.org/ millenniumgoals/2015_MDG_Report/pdf/MDG 2015 rev (July 1).pdf (last visited on Aug. 6, 2018). 
85. Id.

86. Toxic Substances Control Act enacted in 1976 mainly regulates environmental supervision of GMO. See US EPA, Regulation of Biotechnology under TSCA and FIFRA, available at http://www.epa.gov/biotech_rule/pubs/submain.htm (last visited on Aug. 8, 2018).

87. A. Maisashvili et al., Seed Prices, Proposed Mergers and Acquisitions among Biotech Firms, 31 Quarter 3 (2016), available at file://C:/Users/user/AppData/Local/Microsoft/ Windows/INetCache/IE/3LCSH9VO/cmsarticle_540.pdf (last visited on Aug. 8, 2018).

88. USDA Foreign Agricultural Service, supra note 53.

89. Id.

90. J. Browning, R. David \& D. Nair, ChemChina nearing to buy Syngenta for record $\$ 43$ billion, Bloomberg, Feb. 2, 2016, available at https://www.bloomberg.com/news/ articles/2016-02-02/chemchina-said-near-deal-to-buy-syngenta-for-record-43-billion (last visited on Aug. 8, 2018).

91. This argument can be concluded from the EU's practices on legislative principle, labelling regulation, lawsuit in DSB, active promotion of CPB. See Section II of this article.

92. See Xi Jinping: Speech at the Central Conference on Rural Work, in Important Documents Selected and Edited since the 18th National Congress of the Communist Party of China (vol.1) (Literature Research Office of CPC Central Committee ed., 2014).

93. Id.

94. Several Opinions of the Central Committee of the Communist Party of China and the State Council on Implementing the New Concept of Development and Accelerating Agricultural Modernization to Achieve the Goal of Comprehensive Well-off Society [中共中央 国务院 关于落实发展新理念加快农业现代化 实现全面小康目标的若干意见], available at http://www. gov.cn/gongbao/content/2016/content_5045927.htm (last visited on Aug. 8, 2018).

95. USDA Foreign Agricultural Service, Chinese Government Tackles High Production Costs and Uncompetitive Prices in New Agriculture Strategy, GAIN Report Number CH15010, Mar. 19, 2015, available at file://C:/Users/user/AppData/Local/Microsoft/ Windows/INetCache/IE/4HUAGB07/Chinese\%20Government\%20Tackles\%20High\%20 Production\%20Costs\%20and\%20Uncompetitive\%20_Beijing_China\%20-\%20Peoples\%20 Republic\%20of_3-19-2015.pdf (last visited on Aug. 8, 2018). 
